University of Cape Town

\title{
Construction Subcontracting Policy Framework for Developing Local Contractors Capacities in Zambia
}

\author{
M. Mambwe ${ }^{2}$, E.M. Mwanaumo ${ }^{1}$, F. Phiri ${ }^{3}$ and K. Chabota ${ }^{4}$ \\ 1,2,3\& ${ }^{4}$ Department of Civil and Environmental Engineering, School of Engineering, The University of Zambia, Zambia
}

Received 30 Agust 2018; received in revised form 26 Feburary 2020, 15 March 2020 and 24 March 2020; accepted 31 March 2020. https://doi.org/10.15641/jcbm.4.1.644

\begin{abstract}
The Zambian construction industry, like many developing countries has over the past years experienced an imbalance in the distribution of works between local and foreign contractors. In a bid to bridge the gap, the Government of the Republic of Zambia in 2012 introduced a policy on subcontracting which provided for mandatory subcontracting of $20 \%$ of all major contracts to local contractors. There has however been outcries from subcontractors that the policy has not been beneficial. The study sought to investigate subcontracting practices in order to develop a framework for building capacity for local contractors within the construction industry in Zambia. The objective of the study was to explore the regulatory requirements on subcontracting in Zambia and establish the $20 \%$ subcontracting policy inadquescies . The study adopted the mixed method approach in which both semi-structured interviews (main contractors, sub-contractors consultants and project owners) and survey questionnaire were adopted for primary data collection. The questionnaire was distributed to 70 respondents and a response rate of $71 \%$ was attained. The investigation was conducted on 40 projects implemented in Zambia between 2012 and 2015. The study established four major deficiencies of the policy which include: subcontractors do not participate early in the procurement process and are introduced after contract is awarded; no clear guidelines on the implementation of the policy; subcontractors do not take part in determining works; and it is difficult to grow capacity of local contractors using the $20 \%$ subcontracting policy because contractors engaged to be main on projects do not show interest in developing and building local contractors capacity due to lack of incentives. A framework was developed that can be used to meet the study objectives and that of the policy in sucbcontracting and reduce the current inadequacies. The studyrecommended the use of the proposed framework by the government to reduce the current gaps.
\end{abstract}

Keywords: Construction industry, Developing capacities, Local contractors, Subcontracting, Zambia

\section{Introduction}

National economies develop with a thriving construction industry as it is a very significant industrial sector. . Mwanaumo et al. (2018) cited Deloitte (2018) highlighting that at global level, the industry is very enormouse and was valued around USD \$17 trillion in 2017 and is expected to grow to USD 69.4 trillion by 2035. Additionally, the contribution of the contruction industry at global level in relation to the gross domestic product (GDP) is estimated at 15\% of the GDP in 2020 (PricewaterhouseCoopers, 2013) and is expected to increase by $3.9 \%$ per annum to 2030 (PricewaterhouseCoopers, 2017). In South Africa, the construction industry is significant and contributed $3.9 \%$ of the countries' GDP in 2017 according to the PricewaterhouseCoopers (2017) as cited by Lekula (2018) and contributes $11 \%$ of employment (Construction Industry Development Board (CIBD), 2018). In the recent past, the construction industry in Zambia contributed about $10.6 \%$ of the Zambian GDP in 2016 compared to $9.9 \%$ in 2014 , indicating an increase in activity in the development of infrastructure in the country, according to the KPMG 2017 cited by Mwnaumo et al. (2018).

The construction industry in Zambia has however been monopolised by contractors of foreign origin who are aquivalent to $20 \%$ of contractors registered, yet having a market share in excess of $80 \%$ in contract value as noted by the National Concil for Construction (NCC) (2018). This dominance is attributed lack of adequate capacity

\footnotetext{
${ }^{1}$ Corresponding Author.

Email address: erastus.mwanaumo@unza.zm
} 
local contractors according to the report by the Ministry of Works and Supply (2018). To respond to this challenge, the Zambian Government adopted a requirement on the subcontracting of all public works in 2012(NCC, 2014) which saw the increase in the contract sum threshold from $10 \%$ to $20 \%$ of major constructs in the country; . The aim of the $20 \%$ policy threshold in subcontracting was to empower local contractors in order to build their capacity and also to creat jobs (National Council for Construction and Zambia Institute for Policy Analysis and Research, 2017).

According to Kulemeka et al. (2002), the existing variances disables local contractor capacities in relation to registration according to institution requirements And in the recent years, Zambia has seen major construction works that are capital intensive hence are limited to contractors who are in higher grades based on the contractors' classification system in Zambia as highlighted by National Council for Construction (2018) and the National Road Fund Agency (NRFA) (2015) and Conferring to the NCC (2018), local contractors registered in Grade 1 and 2 are only $34 \%$ of the total contractors registered, implying that foreign contractors take the remaining $66 \%$. This eliminates most of the local contractors in participating to procure major construction works since a large number of them are registered in lower categories.

Nonetheless, despite the introduction of the policy, subcontractors, who are the intended beneficiaries, have complained that this policy had not been implemented well and is not beneficial to them (Daily Nation, 2018; Zambia National Broadcasting Corporation, 2015). There has also been little documentation on subcontracting practices in Zambia. This study however, focused developing a manadatory subcontracting practice framework that would help in capacity building of local contractors in the Zambian construction industry. It was thus important to assess the existing subcontracting regulatory framework in Zambia, inaguarate inadequacies of the mandatory $20 \%$ policy manadatory to develop the local contractors' capacities in, then recommend improvements that would culminate into the development of a framework in subcontracting for development of capacity for local contractors. The results will benefit the Zambian government in making policy improvements on the $20 \%$ subcontracting policy. It is envisaged that the study findings would add to the construction industry body of knowledge in relation to subcontracting of local contractors.

\section{Literature Review}

Hoban and Francis (2010), defines subcontractors as being specialists hired by main contractor to perform specific tasks on a project as part of the overall contract. It has been generally accepted that subcontractors play a significant role in the execution of construction work (Akanni \& Osmadi, 2015; Abbasianjahromi, et al., 2013; Hoban \& Francis, 2010). The general contractors' performance is strongly dependent on subcontractors (Albino \& Garavelli, 1998). Mbachu (2008) reinforced this notion and stated that the ability of the general contractor and consultant to deliver the project within time, quality and cost depends largely on the performance of subcontractors. Additionally, the contribution of subcontractors in construction works can be more than $50 \%$ while in some sectors it can be as much as $90 \%$ of the total project value (Kumaraswamy \& Mathews, 2000). According Arditi and Chotibhongs (2005) subcontracting has proved to be efficient and economical in the use of available resources. They argued that qualified subcontractors are usually able to perform their work specialty more quickly and at a lesser cost than the general contractor. It is also noted that subcontracting can improve quality of work and reduce project time and costs (Ng, et al., 2008).

Kulemeka et al. (2015) in their study posit that what prevents performance of local contractors are economic related in nature and concluded that local contractors remain unsustainable and their performance unsatisfactory if governments do not intervene. They further added that in order to address the challenges faced by the Malawian local contractors , the review of policies by the governmebt for the development of small scale contractors programmes ensures that local contractors contribute to the growth of the economy..

While there are ethical issues to be considered in the construction industry, the Transparency International (2005) notes that the industry is classified as the most fraudulent industry worldwide. Studies carried out in various countries such as United States of America (USA) (FMI/CMAA, 2004; Jackson, 2013), Australia (Vee \& Skitmore, 2003), South Africa (Pearl, et al., 2005), and Hong Kong (Fan \& Fox, 2005) provide evidence that the construction industry is plagued with ethical issues due to its substantial capital investments (Adnan, et al., 2012). Additionally, Adman et al. (2012) stated that unethical practices can take place at every phase of a construction project, during planning and design, pre-qualification and tender, project execution and operation and maintenance. Such practices have been seen to result in projects which when completed, are considered unnecessary, unsuitable, overlay complex components, overpriced or delayed as postulated by Hamzah et al. (2010) Akintan and Morledge (2013) and Dainty et al. (2001). Within the Zambian construction industry, unethical issues arise from SME's tendency of selling their subcontracted portions back to main contractors (Muya \& Mukumbwa, 2013).

Literature has shown that there is a general propensity of transmitting huge risks on the projects to small scale contracting firms whose capacity is inadequate to manage the risks (CIDB, 2013; Marzouk, et al., 2013; Laryea, 2010). This makes subcontractors uncertain of main contractors on their authenticity in the association. On the other hand, main contraintors are uncomfortable with subcontractors as they consider them to under employ or employ unskilled employees thus affecting the rate at which the works on site are implemented, thereby leading to conflicts. The subcontractor's lack of capacity is often used as an excuse for harsh conditions and terms leading to failure to meet project set objectives (Construction Excellence, 2004). Various studies to improve subcontracting practice from the point of registration, to selection and monitoring have been done $(\mathrm{Ng}$, et al., 2008). According to Lew et al., (2012), most of the researchers focus on constituents that influence 
subcontracting and on the development of new techniques that can be used for subcontractor selection or management . Kulemeka et al. (2015) notes that it is critical for governments to continuously review policies on contractor development programmes to ensure contribution to their success. While Yoke-Lian et al. (2012) indicated that effective subcontractor selection and monitoring would minimise the problems during construction. Additionally, Laryea (2010) emphasised that governments has a lot to do to enhance capacity for subcontractors to be involved in large projects through the creation of access to capital and improve structures.

\subsection{Subcontracting policy, practices and challenges}

Many countries are encouraging the promotion of SMEs who are mostly subcontracted, strive to industrialise and bring about economic development, for governments developing policies that encourage subcontracting (Hoban \& Francis, 2010). The participation of local constructing firms as subcontractors to foreign firms is an important element in the concept of skills and technology transfer as well as building the capacities of local contractors (Abu Bakar \& Tufail, 2012). Choudry et al. (2012) pointed out that as a deliberate policy, governments should formulate regulatory bodies to monitor the policy implemetation on subcontracting.

However, CIBD (2013) postulate that successful skills and technology transfer happens if both the main and subcontractors are on long-term strategic relationships, as most subcontractors are reluctant to share confidential information with other companies, especially financial information.

Wells (2000) postulates that the construction industry in Africa is characterised by extensive subcontracting, temporary and insecure employment, and poor working conditions. The CIDB (2013) study on subcontracting in the construction industry in South Africa, indicated that legislative and policy interventions around subcontracting should be aimed at improving the environment within which subcontracting takes place. In South Africa, various projects that are related to the public sector encourage the development of local economies by the adherence to set policies and regulatory requirements as can be seen in the targets set on the socio-economic front on training and development of skills, employment of the locals and the black economic empowerment , (CIDB, 2013). However, Mwanaumo et al. (2014) argued that contractors feel that such requirements on projects have worked well especially in creating employment, but are difficult to sustain in times of difficult economic climate where projects are hard to come by.

Cheng et al. (2011) in the research on evluating subcontractor performance proposed twelve (12) significant factors to be included in the subcontractor selection policy and concluded that trained input-output mapping relationship and subcontractor final scores should be used as key policy factors in building subcontractor capacity. However, Laryea, (2010) in the Ghana study on the evolution of indegenous constractors revelead that with the dominance of foreign contractors, local contractors lack capacity to carry out major projects and hence recommended the government to develop policies that would encourage local participation including subcontrating them in huge contracts to develop skills.

It has been argued that there is no common practice that is standard, in the formulation of subcontracting policy and each country comes up with its own framework based on the local factors, prime contractors, clients the other related policies that support subcontracting (Choudry, et al., 2012). They noted that some of the factors that could positively encourage local contractor capacity building should include technical and professional training through knowledge and skills transfer in financial, managerial, technical and technology transfer; efficient communication; evaluate roles and responsibilities for enforcement. This was also affirmed by CIDB (2013) and Martin (2010) who added that these factors should be guiding the subcontracting policy formulation and should aim at improving the environment in which subcontracting takes place, the contract forms and improve at management level the organisational aspects of the attached to subcontracting firms.

Thwala and Mvubu (2007) however, suggested that identification of local capacity is imperative for planning purposes in future projects. They also added that the usage of an integrated construction unit method of procurement helps in growing local contractors in economies such as that in developing countries. Kalemuka et al. (2015) and CIBD (2013) emphasised training at planning and design stage be incorporated for local contractors. While Muya \& Mukumbwa (2013) proposed that a policy should have integrity improvements in the supply of equipment done by deducting costs at the beginning of certification, and consultants should approve payments to be executed by local contractors who are expected to be available for a particular period they are engaged. A similar notion was also attested by Abbasianjahromi, et al. (2013).

Nonetheless, though subcontracting is widely used in the developed world, it has been criticised to bring about challenges for the firm that is subcontracted and these challenges are mostly common in developing countries than in developed countries according to Mlenga (2002). The Zambian $20 \%$ subcontracting policy features provide for empowering and capacity building of local contractors, , employment creation for Zambian people and mandatory subcontracting of $20 \%$ of the contract sum be allocated to local contractors on all public projects awarded to foreign contractors. However, Zambia has been experiencing challenges to implement the policy requirement (Kaliba, 2015). Kaliba (2015) pointed that the $20 \%$ subcontracting policy is not legally supported as it has not been passed through parliament for ratification and has no existing guideline for implementation, while main contractors are uninterested in helping local contractors, and there is evidence of poor planning to help the local contractors build capacity in managing subcontracted works. While Choudry et al. (2012) noted that knowledge sharing is very power between main contractors as they prefer to continue enjoying the monopoly.

Several challenges have been highlighted from subcontracting firms by the CIDB (2013) and range from lack of security payment, weak management practices, poor attitudes, skills shortages, lack of working capital and failure to meet up with the competition from low 
barriers to entry. These challenges inhibit subcontractors to grow their companies and move to a higher grading system, and thus fail to execute quality work. However, some improvements to the subcontracting policies in countries were similar or related policies have been adopted have suggested review of the policy if its not working (Abbasianjahromi, et al., 2013). This was also affirmed by Kaliba (2015) though he noted that even if the policy can be reviewed, the client needs to have a long term plan on assisting local subcontractors in capacity building to meet deliverable milestones.

\section{Research Methodology}

The study sought to examine practises in subcontracting to develop a framework of capacity building for the Zambian local contractors within the construction sector. The study adopted the exploratory mixed method approach in which semi-structured interviews and a survey questionnaire were used. Only 26 out of the targeted 30 stakeholders participated in the interviews to obtain an in-depth understanding (Creswell, 2014) of the subcontracting practices in Zambia. The target group included management of subcontractors, main contractors, clients and consultants. Data was captured through audio recording and note taking and was analysed using thematic analysis. Purposive sampling was used because it purposely targets a group of people perceived to be reliable and useful to inform the field survey questionnaire (Creswell, 2014) which was pretested for validity. A sample size of 70 was adopted for convenience of which a total of 50 questionnaires were successfully completed giving a response rate of $71.4 \%$ and hence acceptable (Creswell, 2014). The distribution was as presented in Table 1.

Table 1: Questionnaire distribution per project and category of respondents

\begin{tabular}{lcc}
\hline Group & $\begin{array}{c}\text { No. of } \\
\text { projects }\end{array}$ & $\begin{array}{c}\text { No. } \\
\text { distributed }\end{array}$ \\
\hline Clients & 5 & 10 \\
Consultants & 3 & 20 \\
Main Contractors (Grade 1 to 3) & 8 & 10 \\
Subcontractors (Grade 4 to 6) & 24 & 30 \\
Total & 40 & 70 \\
\hline
\end{tabular}

The structured questionnaire survey was based on the 40 projects implemented between 20th March 2012 and 20th April 2015 and targeted foreign contractors, local contractors, consultants and clients. Clients included technical persons working for Government Ministries and Agencies. Consultants were drawn from member firms of the Association of Consulting Engineers while contractors were drawn from organisations registered with the National Council for Construction (NCC) (2014) in category B, C and R and grades 1 to 6 which was biased to road and building construction sectors. The study respondents rated the statements using a 5-point Likert scale of 1 to 5 . The results from the survey questionnaire was analysed using descriptive statistical techniques while Microsoft Excel Spreadsheets and Statistical
Package for Social Science (SPSS) Version 26 were used as tools.

\section{Results}

The following are the results from the survey questionnaire approach:

\subsection{Category and Grade of Companies' registration}

This section of the findings presents information on characteristics of the respondents who were contractors. The results represent the contractors in the Building (B), Civil engineering $(\mathrm{C})$ and roads $(\mathrm{R})$ categories. These are recipients of the many public contracts related to the construction of scools and hospitals, health posts, roads and bridges. The highest percentage of the respondents at $27 \%$ came from the category $4 \mathrm{R}$ followed by the category $1 \mathrm{R}$ at $22 \%$; the category $6 \mathrm{R}$ at $14 \%$; the categories of $1 \mathrm{~B}$, $1 \mathrm{C}$ and $6 \mathrm{~B}$ were at $9 \%$ and, lastly, those in $5 \mathrm{R}$ and $5 \mathrm{~B}$ categories were at $5 \%$. The distribution of contractors according to categories and grades obtained from NCC is presented in Table 2 .

Table 2: Category and Grade of companies' registration

\begin{tabular}{lc}
\hline $\begin{array}{c}\text { Category and Grade of } \\
\text { companies }\end{array}$ & $\begin{array}{c}\text { Percentage of } \\
\text { Respondents }\end{array}$ \\
\hline $1 \mathrm{R}$ & $22 \%$ \\
$4 \mathrm{R}$ & $27 \%$ \\
$5 \mathrm{R}$ & $5 \%$ \\
$6 \mathrm{R}$ & $14 \%$ \\
$1 \mathrm{~B}$ & $9 \%$ \\
$1 \mathrm{C}$ & $9 \%$ \\
$5 \mathrm{~B}$ & $5 \%$ \\
$6 \mathrm{~B}$ & $9 \%$ \\
\hline
\end{tabular}

\subsection{Contractual arrangements}

The proportion of respondents who had been involved in traditional contractual arrangement was $71 \%$ followed by those who had been involved in the design and build at $16 \%$. The third common arrangement was the Integrated Construction Unit (ICU) which accounted for $10 \%$ while $3 \%$ had experience in the Management Contracting method. Table 3 represents a summary of the findings.

Table 3: Results of respondents based on contractual arrangements

\begin{tabular}{lc}
\hline Contractual arrangements & $\begin{array}{c}\text { Percentage of } \\
\text { Respondents }\end{array}$ \\
\hline Traditional method & $71 \%$ \\
Management contracting & $3 \%$ \\
Design and Build & $16 \%$ \\
Integrated Construction Unit & $10 \%$ \\
\hline
\end{tabular}

On the preference of the contractual method for the subcontracting policy, it was established that $48 \%$ of the respondents favoured traditional methods of procurement while $45 \%$ were of the view that the management contracting method would be better in implementing the policy. However, $5 \%$ and $2 \%$ preferred integrated construction unit, and design and build method respectively. 


\subsection{Analysis on implementation, constraints and improvements to the policy}

The respondents were asked to rate statements concerning the mandatory subcontracting policy on a Likert scale of 1 to 5 . A total of 46 statements obtained from preliminary interviews and literature review were adopted for this study. The nine statements relating to inadequacies of the mandatory subcontracting policy were established and included "the $20 \%$ subcontracting policy is not legally supported as it did not pass through parliament for ratification; and difficult to grow capacity of local contractors using the $20 \%$ subcontracting policy as main contractors are not interested in building capacities of local contractors due to lack of incentives".

Other statements include "the lack of strategic plan on subcontracting makes it difficult to build capacity of local contractors, no participation of subcontractors in the determination of work; and main contractors want to retain maximum benefits, thus reluctant to subcontract". Additionally, main contractors are not willing to impart skills on subcontractors in order for them to continue enjoying the monopoly; lack of local contractor capacity infringes on main contractors to build capacity for local contractors ; there are no clear guidelines on the implementation of the policy. Lastly, subcontractors do not participate in the procurement process and are only introduced after contracts are awarded. These statements are similar to the ones in the literature reviewed such as by CIBD (2013), Kulemeka et al. (2015), Kaliba (2015), Mbachu (2008), Abbasianjahromi, et al. (2013) and Thwala and Mvubu (2007).

4.3.1 Inadequacies in the $20 \%$ mandatory subcontracting policy

The statements submitted by respondents were analysed with respect to the $20 \%$ subcontracting policy inadequescies. The results show that out of the nine statements, six had a man mean score greater that 3.5 . The descriptive statistics are presented in Table 4 indicting that there were dissimilarities in the way respondents alleged the existing inadequacies of the mandatory subcontracting policy by different construction practitioners in Zambia.

Table 4: Descriptive statistics of inadequacies in the mandatory subcontracting policy

\begin{tabular}{|c|c|c|c|c|}
\hline No. & Statement & $\begin{array}{l}\text { Mean } \\
\text { score }\end{array}$ & Variance & $\begin{array}{l}\text { Mean score } \\
\quad>3.5\end{array}$ \\
\hline 1. & $\begin{array}{l}\text { The } 20 \% \text { subcontracting policy is not legally supported as it did not pass through } \\
\text { parliament for ratification }\end{array}$ & 3.39 & 2.021 & - \\
\hline 2. & $\begin{array}{l}\text { Difficult to grow capacity of local contractors using the } 20 \% \text { subcontracting } \\
\text { policy as a result of lacking interest by main contractors in local contractor } \\
\text { capacity building due to lack of incentives. }\end{array}$ & 3.64 & 1.801 & Yes \\
\hline 3. & $\begin{array}{l}\text { Lack of strategic plan on subcontracting makes it challenging to build local } \\
\text { contractors capacity. }\end{array}$ & 3.89 & 1.445 & Yes \\
\hline 4. & No participation of subcontractors in the determination of work & 3.81 & 1.815 & Yes \\
\hline 5. & Main contractors want to retain maximum benefits, thus reluctant to subcontract & 4.20 & 1.672 & Yes \\
\hline 6. & $\begin{array}{l}\text { Main contractors are not willing to impart skills to subcontractors so as to } \\
\text { continue enjoying the monopoly }\end{array}$ & 3.48 & 2.211 & - \\
\hline 7. & $\begin{array}{l}\text { Lack of capacity of local contractors make it difficult to build capacity of local } \\
\text { contractors by main contractors. }\end{array}$ & 3.00 & 1.745 & - \\
\hline 8. & No clear guidelines on the implementation of the policy & 3.67 & 1.546 & Yes \\
\hline 9. & $\begin{array}{l}\text { Subcontractors don't participate in the procurement process and only introduced } \\
\text { after contract is awarded }\end{array}$ & 4.10 & 1.635 & Yes \\
\hline
\end{tabular}

The statements from Table 4 were further analysed in order to identify those which were either important or very important. The cut off point for the mean score was set at 3.5. Out of the nine statements, six were found to have a mean score greater than 3.5. After taking a standard t-test it was found that only four statements were statistically significant $(\mathrm{p}<0.05)$ and they include: subcontractors don't participate in the procurement process and only introduced after contract is awarded; and no participation of subcontractors in the determination of work. The other two are: no clear guidelines on the implementation of the policy, and difficult to grow capacity of local contractors using the $20 \%$ subcontracting policy as there is disinterest in capacity building of local contractors by main contractors because of lacking incentives.

4.3.2 Improvements to the $20 \%$ mandatory subcontracting policy

The results from this part of the questionnaire were analysed with respect to respondents' perception on possible improvements to the implementation of the subcontracting policy. The initial stages of the analysis used descriptive statistics and the results are presented in Table 5 .

\subsection{Interview results}

The purpose of the interviews was to obtain an in-depth understanding on how the various stakeholders in Zambia view $20 \%$ subcontracting policy. The interviewees agreed that "work allocation has to be done by the engineer/consultant at design stage instead of foreign or main contractors in order to remove bias". The subcontractors indicated that they needed to be involved in work allocation.

On establishing the common methods of engaging contractors, the interviewees stated that "it would be difficult to achieve the objective of empowering and creating jobs for the local contractors if main contractors were left alone to engage subcontractors". Prefernance on the nominating of clients was justified that "it would enhance fairness and reduce the cases of main contractors buying off subcontracts whilst pretending to have subcontracted". 
On awareness of the subcontracting policy, the results showed that generally the respondents understood the main features of the $20 \%$ subcontracting policy. Over $90 \%$ of the interviewees stated that the main features of the subcontracting policy included:

(i) Mandatory subcontracting of $20 \%$ of the contract sum to local contractors on public projects provided the contract sum was above Thirty Million Kwacha and contract was awarded to a foreign contractor;

(ii) Building capacities and empowering local contractors; and

(iii) Fostering employment creation for the Zambian people.

To assess if the policy addresses the interests of both main and subcontractors, about $76 \%$ indicated that the current policy does not support the interest of contractors and their subcontractors. However, when asked about the functionality of the laws in the construction sector, majority of the respondents, $64 \%$, were affirmative while $36 \%$ were not sure.
To establish challenges in implementing the subcontracting policy, the data was recoded and analysed qualitatively. The main reasons, in order of importance, attributed to the policy's failure to meeting the interests of the main and subcontractors included:

(i) Lack of interest by Main foreign contractors to build capacity of local contractors;

(ii) Main contractors view subcontractors as potential competitors;

(iii) Main contractors not willing to subcontract $20 \%$ of the contract sum;

(iv) Main contractors allocate low value works to subcontractors so that they maximise profits;

(v) Lack of experience, personnel, equipment and poor financial resources among local subcontractors;

(vi) Insufficient capacity in project management among subcontractors inhibits the possibility of subcontracting $20 \%$ of huge or high value projects.

Table 5: Descriptive statistics of constraints to the subcontracting policy

\begin{tabular}{|c|c|c|c|c|}
\hline No. & Statement & $\begin{array}{l}\text { Mean } \\
\text { score }\end{array}$ & Variance & $\begin{array}{l}\text { Mean score } \\
\quad>3.5\end{array}$ \\
\hline 1. & $\begin{array}{l}\text { Reviewing the current policy on subcontracting so that is can include supporting } \\
\text { and key sectors considered significant in the construction industry. }\end{array}$ & 4.59 & 0.455 & Yes \\
\hline 2. & $\begin{array}{l}\text { Need for the client to strategically plan on local contractor capacity building } \\
\text { through deliverables that are attainaible e.g. upgrading in every } 3 \text { years, at least } 10 \\
\text { Grade } 1 \text { contractors. }\end{array}$ & 4.50 & 0.511 & Yes \\
\hline 3. & $\begin{array}{l}\text { Identification of local contractors by clients who have the capacity to develop so } \\
\text { that they can be placed in } 5 \text { years deliberate programmes. }\end{array}$ & 4.12 & 1.110 & Yes \\
\hline 4. & $\begin{array}{l}\text { Using Interated Construction Unitmethod of procuring works done by local } \\
\text { contractors for them to grow. }\end{array}$ & 4.16 & 0.723 & Yes \\
\hline 5. & $\begin{array}{l}\text { Training identified local contractors by consultants based on the works identified. } \\
\text { Client to procure equipment from suppliers for the identified local contractors and }\end{array}$ & 4.00 & 1.333 & Yes \\
\hline 6. & $\begin{array}{l}\text { start deducting the cost through interim payment certificates for a medium term } \\
\text { period }\end{array}$ & 3.76 & 1.730 & Yes \\
\hline 7. & Consultants approve payments made by local contrators identified & 4.10 & 0.802 & Yes \\
\hline 8. & The project design to include identified local contractors training & 4.18 & 0.653 & Yes \\
\hline 9. & $\begin{array}{l}\text { Ensure the availability of work for a period of } 3 \text { years for all identified local } \\
\text { contractors. }\end{array}$ & 4.14 & 0.833 & Yes \\
\hline 10. & $\begin{array}{l}\text { Provision of development of skills and employment with main contractors } \\
\text { continues in other related projects }\end{array}$ & 4.27 & 0.883 & Yes \\
\hline
\end{tabular}

\section{Discussion}

The study identified four major inadequacies of the $20 \%$ mandatory subcontracting policy. The first one relates to non-participation of subcontractors in the procurement process as they are introduced onto the project after award of contract to the main contractor. This inadequacy was also similar to the insufficiency that was highlighted by Hoban and Francis (2010) in their study on improving the relationship between contractors and subcontractors. The second inadequacy relates to non-participation of subcontractors in the determination of work. This was also highlighted as a major concern in the procurement system of subcontractors and considered a major challenge in traditional procurement method (Mwanaumo, et al., 2014; Akintan \& Morledge, 2013) culminating to inappropriate periods of activities that critical at projects duration of critical activities. However, the study found that adequate and broad view of information about the works was not properly done, thereby increasing programme failure possibilities and leading to project delays (Hoban \& Francis, 2010; CIDB, 2013). To avert this inadequacy, it would be necessary to engage subcontractors during the design stage, a sentiment which was shared by $\mathrm{Ng}$ et al. (2008). The awareness level in technical professional subcontracting was found to be high from clients, consultants and contractors, and a similar result was affirmed by Akanni and Osmadi (2015) that such subcontracting was widely used.

The study also established the third inadequacy that lack of clear guidelines on the implementation of the 
policy was one of the major deficiencies of the mandatory subcontracting policy as applied in Zambia. CIDB (2013) underscored the importance of legislation and policy interventions around subcontracting firms in a bid to improve the environment within which subcontracting takes place. In the absence of clear guidelines, policy implementation would be a challenge and subject to individual interpretation (CIDB, 2013). Policy should be accompanied by clear strategies on building local contractors capacities. The strategy must be clear as how many local contractors have to be upgraded according to the NCC classification (NCC, 2018). This relates to Kulemaka et al. (2015) on the notion that proving an environment that empowers an small subcontracting firms include the elimination of entry to market barriers , growth and sustainability.

The fourth inadequacy established that the $20 \%$ subcontracting policy made it futile for local contractors to build capacity because thare was lack of interest by main contracors to assit build capacity attributed to due to lack of incentives. This finding relates to the adversarial relationship which exists between main contractors and subcontractors. The findings agree with Kaliba (2015) and Choudry et al. (2012) whose assertion was based on unconcerned main contractors in developing local contractors subcontracted under them.

Main and subcontractors operate with the conflict theory which emphasises the presence of conflicting forces in society, social structures, groups and individuals generally (Abbasianjahromi, et al., 2013; Akintan \& Morledge, 2013). The theory perceives the society of humans as a gathering of interest groups and individual that are competitive with each other in relation to motives and expectations. However, this was non affirmative from the study which established that the Zambian construction industry's main contractors are not willing to subcontract their works.

Subcontractors can therefore be enganged through nomination by clients. However, Yoke-Lian et al. (2012) and Laryea (2010) difficulties are attained when striving to empower and create jobs for loal contractors whenever main contractors are engage subcontractors on their own.The study disclosed that preference in the nomination of subcontractors by clients enhances fairness and reduces the cases of main contractors buying off subcontracts whilst pretending to have subcontracted. The study findings is affirmative with that of Mwanaumo et al. (2018) in which subcontracts were alleged to be bought off by main contractors. Hence, it is logical to conclude that, once main contractors were left alone to implement the policy in its current state, very few subcontractors would be engaged.

Improvements and modifications to the policy enables mandatory subcontracting policy reviews that includes all other sectors in the Zambian construction industry in order to empower and create jobs for local contractors. This is in line with Kumaraswamy and Mathews (2000) who avowed that the contribution of subcontractors in other sectors of construction is more than $50 \%$ and as much as $90 \%$ of the total project value to a construction process.

Other improvements include the identification of local contractors with potencial for growth under a deliberate programme; using Interated Construction Unitmethod of procuring works done by local contractors for them to grow.; training identified local contractors by consultants based on the works identified.; and Consultants approve payments made by local contrators. These relates to findings by Thwala and Mvubu (2007). The study also gathered that at project design, training of local contractors be included; ensuring that works are made accessible in not less than 3 years for local contractors identified; and the continuation of skills development and employment in other projects subcontracted by main contractors for the identified local contractors and are in line with CIDB (2013).

The study established that empowering and developing capacities of small scale contractors involves strategic planning on the part of government. The findings on this study conforms with the findings of Kulemeka (2015) who established that the comprehensive and detailed planning processes with set quantitative and qualitative targets guide implementing institutions. However, Thwala and Phaladi (2009) stated in their study that significant lessons can be drawn from those initiatives that have been done before such as advocate the interest of emerging contractors and ensure that policies and procedures in the construction industry create an environment conducive to the development and promotion of emerging contractors; increase the participation of emerging contractors in construction activities; substantially increase the emerging construction enterprises share of work opportunities within the public sector. Additionally, several proposals were made to develop a subcontracting policy framework as a starting point and a means to develop local contractors' capacities so that they can participate major contracts implementation in the country. This was the basis and one of the main study objective.

\subsection{Development of the subcontracting policy framework}

The study established that the majority of construction companies in Zambia are small scale in nature. Thwala and Phaladi (2009) mentioned in their study that one success factor was not effective to the success of small scale contractors unless different factors are considered to ensure that the capacity is developed in the local contractors, a model was developed.

The subcontracting framework was developed to ameet the objectives of the $20 \%$ the $20 \%$ mandatory subcontracting policy as illustrated in Figure 1. The key stakeholders involved are: the client (public, private or quasi-government), the consultant (engineers, architects, and quantity surveyors), the equipment suppliers or key material suppliers, commercial banks and financial institutions, the main contractors and the subcontractors. The framework is in two ways, firstly the client can make a preliminary assessment whether or not proposed project can be used for capacity building program. And secondly, if a project is useful for capacity building, the client proceeds with the procurement of a design and supervision consultant whose responsibility includes: designing of the project; preparation of project specifications as well as work breakdown packages for the subcontractors; and project supervisionThe consultant can 
then allocate a prime cost sum to identified works for subcontracting and then propose the equipment and key project materials required for the subcontracting works.

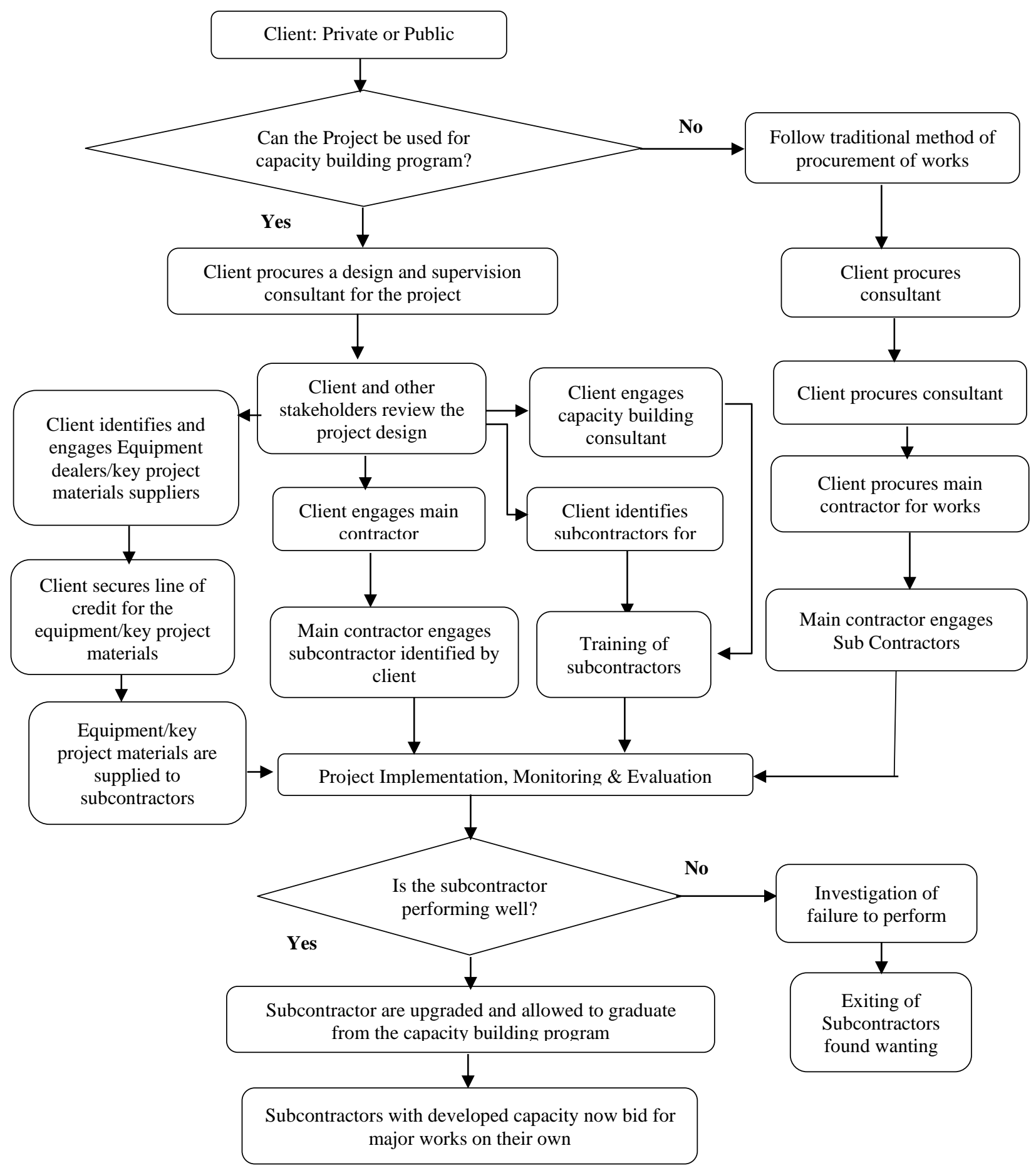

Figure 1: Subcontracting framework for capacity building

Key points regarding the proposed framework include: the client would provide advance payment to subcontractors to kick start the subcontracting works; a meeting would be set up for all the stakeholders involved to explain the roles and responsibilities of all the parties to the contract; during the project implementation process, the cost of the procured equipment/key project materials would be deducted proportionately through the interim payment certificates (IPCs); the authorisation on the use of funds would not be left to the subcontractors alone; the client would guarantee contracts for the earmarked subcontractors for the project duration to ensure that the equipment and or key project materials procured during this time would be paid for by the subcontractors from proceeds of the project.

\subsection{Stages and roles of the stakeholders in the framework}


The client is the employer of the project team members. The client has the responsibility of empowering and building capacities of its citizens. The client will have the overall responsibility and control of the project. The client will have to assess initially if the project can be used for capacity development of subcontractors or not.

The consultant is responsible for designing and supervising the works. The consultant would be responsible for allocating works for subcontracting at design stage. Works to be subcontracted would be reviewed together with the client and other stakeholders upon completion of the designs by the consultant. At this stage, comments on work allocation are added. The consultant's overall responsibility is of delivering the project.

The capacity development consultant is responsible for supervising and providing training to the subcontractors. The training package include technical and financial management while subcontractors will be encouraged to maintain qualified personnel. The capacity development consultant would advise and report to the client on all matters relating to subcontracting and capacity development of subcontractors.

This stage shall be used to review the designs and works allocated to subcontractors. The stakeholders involved in the review process include the capacity development consultant, design consultant, client and any other stakeholders relevant to the capacity development programme. This stage would eliminate the allocation of low value works to subcontractors.

The client will issue the expression of interest for local contractors. Then the client will have a list of local contractors according to their specialisation. Capacity development criteria would be developed in order to shortlist the local contractors. The subcontractors for capacity development programme would then be nominated from the list of approved local contractors.

The equipment/key materials suppliers will provide materials, equipment and back up spares to the subcontractors through the projects. The suppliers of equipment will provide on-site service and training to subcontractors' personnel for sustainability purposes. Key materials like cement, steel, fuel, bitumen, aggregates to mention but just a few would provide reasonable boost to the implementation of the project by the subcontractors who are usually financially week compared to major foreign contractors.

The role of main and subcontractors would be to deliver the project according to the specifications to the client. The subcontractors will have a duty to learn and develop their technical and financial management skills from the main contractors and consultants.

The scope of works for subcontractors will be well defined in the contract documents. The contracts will also

\section{References}

Abbasianjahromi, H., Rajaie, H. \& Shakeri, E., 2013. A frameworkwork for subcontractor selection in the construction industry. Journal of Civil Engineering and Management, 19(2), pp. 158-168.

Abu Bakar, A. H. \& Tufail, M. A., 2012. Transforming capability of indegenous contrators through technology provide the criteria on how performance and quality required for the works will be measured, the methods for performance measurement and the acceptance. The terms and conditions for subcontracting will be included in the contract documents, especially payment terms, retention, advance payment bond, defect liability period and liquidated damages.

The monitoring of the subcontractors and the project would be carried out for purposes of checking progress and evaluating the capacity building programme. The evaluation would also be carried out to assess which subcontractors would graduate from the programme. The process would also be used to reassess those subcontractors failing to perform. Performing subcontractors would be recommended for upgrade according to NCC grades and categories. At the end of the project, it is expected that some subcontractors would have been capacitated and upgraded. The upgraded local contractors would then be assisted to tender jobs with high values especially those who will be in Grades 1 and 2 .

\section{Conclusions and Recommendations}

The paper examined the mandatory $20 \%$ subcontracting policy in the Zambian construction sector. The policy was formulated to help bridge the gap between firms of foreign origin and indigenous contractors. Through this study, it was established that the current policy has four major deficiencies in as far as meeting the objectives of empowering and building capacities of local contractors is concerned.

The mandatory subcontracting policy operates within the traditional procurement realm where the main contractors normally engage subcontractors to carry out part of their contractual work based on the skill and capacity set which the subcontractors supposedly possess. This conflicts with the objective of the policy which emphasizes on the transfer of skills and building capacities of local contractors. Thus, even though the policy is in place, the implementation of this policy could be difficult. The study developed a subcontracting policy framework that would help build local contractor capacities in Zambia so that they can be able to participate in the construction projects.

It would therefore be imperative that the procurement and contracting strategies be modified if the objectives of the policy are to be met. The Government of Zambia should thus review the method of engagement, work allocation system and formulate clear guidelines on implementation of the policy. The procurement and contracting strategies should also take into consideration the ever present adversarial tendencies that exist between main contractors and subcontractors.

transfer: A Malaysia experience. World Applied Sciences Journal, 16(10), pp. 1450-1461.

Adnan, H., Hashim, N., Yusuwan \& Ahmad, N., 2012. Ethical Issues in the Construction Industry: Contractor's Perspective. Journal of Social and Behavioural Science, Volume 35, pp. 719-727.

Akanni, P. O. \& Osmadi, A. B., 2015. Relative improtance of trust attributes in subcontractors selection 
in Nigeria. Australian Journal of Basic and Applied Science, 9(7), pp. 284-288.

Akintan, O. A. \& Morledge, R., 2013. Improving the Collaboration between Main Contractors and Subcontractors within Traditional Construction Procurement. Journal of Construction Engineering.

Albino, V. \& Garavelli, A., 1998. A Neural Network Application to Subcontractor Rating in Construction Firms. International Journal of Project Management, 16(1), pp. 9-14.

Arditi, D. \& Chotibhongs, R., 2005. Issues in subcontracting practice. Journal of Construction Engineering and Management, 131(8), p. 866876.

Central Statistical Office, 2014. Zambia in Figures, Lusaka: Government Printers, Government of the Republic of Zambia.

Cheng, M., Tsai, H. \& Sudjono, E., 2011. Evaluating subcontractors performance using evolutionary fuzzy hybrid neutral network. International Journal of Project Management, 29(3), pp. 349-356.

Choudry, R. M., Hinze, J., Arshad, M. \& Gabriel, H. F., 2012. Subcontracting practices in the construction industry of Pakistan. Journal of Construction Engineering and Management, Volume 12, pp. 1353-1359.

CIBD, 2018. Construction Monitor - Employment Q3, Johannesburg, South Africa: CIBD.

CIDB, 2013. Subcontracting in the South African Construction Industry: Opportunities for Development, South Africa: CIDB.

Construction Excellence, 2004. Partnering in Practice. [Online] Available at: http://www.constructingexcellence.org.uk/download.jsp? url $=\%$ Fpdf $\%$ wFcase_studies $\% 2$ Fwestern_challenge.pdf

Construction Industry Development Board (CIDB), 2013. Subcontracting in the South African Construction Industry: Opportunities for Development, Johannesburg, South Africa: CIDB.

Creswell, J. W., 2014. Researcg design; qualitative, quantitative, and mixed methods approaches. 4th ed. Thousand Oaks, Carlifornia : Sage Publications.

Daily Nation, 2018. Local Contractors cry foul over contracts. [Online] Available at: http://zambiadailynation.com

Dainty, A. R., Briscoe, G. H. \& Millett, S. J., 2001. Subcontractor perspectives on supply chain alliances. Construction Management and Economics Journal, 19(8), pp. 841-848.

Deloitte, 2018. Global Powers of Construction, Madrid, Spain: Communication, Brand and Business Development Department.

Fan, C. N. L. \& Fox, P. W., 2005. Ethical Issues in the construction industry, Construction Industry, Hong Kong: Institute Construction Industry Institute.

FMI/CMAA, 2004. Survey of Construction Industry Ethical Practices and Issues, s.l.: Management Consultant for the Construction Industry and Construction Management Association of America .

Hamzah, A., Wang, C. \& Yap, X., 2010. How professional ethics impact construction quality: perception and evidence in a fast developing economy. Scientific Research and Essays, 5(23), pp. 3742-3749.
Hoban, A. M. \& Francis, V. E., 2010. Improving Contractor/Subcontractor Relationships through Innovative Contracting. s.1., CRC Press.

Jackson, B., 2013. Primanry factors influencing bid mark-up size decisions of general contractors in Kuwait. Journal of Finance Management of Property and Construction, 18(1), pp. 53-75.

Kaliba, C., 2015. Knowledge creation, integration and management - A study of civil engineerig consulting firms, Lusaka: s.n.

Kulemeka, G. K. G., Price, A. D. F. \& McCaffer, R., 2002. Emperical inestigation of construction contractors' organisational learning. Journal of Construction Engineering and Management, 128(5), pp. 385-391.

Kulemeka, P. J., Kalulunga, G. \& Morton, D., 2015. Critical factors inhibiting performance of small and medium scale contractors in Sub-Saharan Region: A cas of Malawi, Malawi: s.n.

Kumaraswamy, M. M. \& Mathews, J. D., 2000. Improved subcontractor selection employing partnering principles. Journal of Management in Engineering, 16(3), pp. 47-57.

Laryea, S. A., 2010. The evolution of indegenous contractors in Ghana. Accra, Ghana, s.n., pp. 579-588.

Lekula, N., 2018. Construction industry a good growth barameter. [Online] Available at: https://www.iol.co.za/business-

report/economy/construction-industry-a-good-growthbarometer-14258859 [Accessed 28 March 2020].

Martin, L., 2010. Knowledge transfers in South African Construction Industry: Focus on Civil Engineering Constractors, s.l.: s.n.

Marzouk, M. M., El Kherbawy, A. A. \& Khalifa, M., 2013. Factors influencing sub-contractors selection in construction projects. Housing and Building National Research Centre Journal, pp. 150-158.

Mbachu, J., 2008. Conceptual Framework for the Assessment of Subcontractors ${ }^{\text {ee }}$ Eligibility and Performance in the Construction Industry. Construction Management and Economics Journal, Volume 26, pp. 471-484.

Ministry of Works and Supply, 2018. Policy Statement: Empowerment of Zambian owned Local Road Contractors, Lusaka: Government Printers, Government of the Republic of Zambia.

Mlenga, G. J., 2002. An Investigation of Subcontracting Linkages in Botswana. Journal of Applied Sciences, Volume 2, pp. 295-299.

Muya, M. \& Mukumbwa, B., 2013. Integrity Systems in Construction Organisations in Zambia. International Journal of Architecture Engineering and Construction, 2(2 (June 2013)), pp. 106-119.

Mwanaumo, E. M., Thwala, W. D. \& Mambwe, M., 2018. Multi Stakeholder Consultative Framework for Construction Health and Safety: Role of Client and Project Manager. Livingstone, Zambia, DII Conference Series, pp. 235-246.

Mwanaumo, E., Thwala, W. D. \& Pretorius, J. H., 2014. Assessing Health and Safety Requirements in Construction Contracts in Botswana. Journal of Economics and Behavioural Studies, 6(1), pp. 37-43.

National Council for Construction and Zambia Institute for Policy Analysis and Research, 2017. Baseline Survey 
of the Zambian Construction Industry: Final Report, Lusaka: National Council for Construction and Zambia Institute for Policy Analysis and Research.

National Council for Construction, 2014. Annual Report, Lusaka: NCC.

National Council for Construction, 2018. National Council for Construction 2018 Annual Report, Lusaka, Zambia: NCC.

National Road Fund Agency (NRFA) , 2015. Road Sector Annual Report, Lusaka: NRFA.

Ng, S., Luu, C. \& Chu, A., 2008. Dilineating criteria for cubcontracting registration considering divergence in skill base and scales. International Journal of Project Management, Volume 26, pp. 448-456.

Pearl, R., Bowen, P., Makanjee, N. \& Evans, K., 2005. Professional ethics in the South African construction industry - A pilot study. Brisbane, Australia, s.n.

PricewaterhouseCoopers, 2013. Global Construction growth to outpace the GDP this decade. [Online] Available at: https://in.reuters.com/article/idINIndia55293920110303 [Accessed 3 March 2020].

PricewaterhouseCoopers, 2017. Global Construction 2030: A global forecast for the construction industr, Vietnam: PWC.
Thwala, W. D. \& Mvubu, M., 2007. An evaluation of small contractor development programme in Swaziland. CIB World Building Congress.

Thwala, W. D. \& Phaladi, M. J., 2009. An explorattory study of problems facing small contractors in the North West Province of South Africa. African Journal of Business Management, 3(10), pp. 533-539.

Transparency International, 2005. Global Corruption Report, London: Pluto Press.

Vee, C. \& Skitmore, R. M., 2003. Professional ethics in the construction industry. Journal of Engineering Construction and Architectural Management, Volume 10, pp. 117-127.

Wells, J., 2000. The Role of the Informal Sector of the Construction Industries in Developing Countries: Best Practices Project, s.1.: CIB Task Group 29 on Developing Countries.

Yoke-Lian, L., Hassim, S., Muniandy, R. \& Teik-hua, L., 2012. Review of Subcontracting Practice in Construction Industry. International Journal of Engineering and Technology, 4(4).

Zambia National Broadcasting Corporation, 2015. Banks favouring foreign contractors. [Online] Available at: http://znbc.co.zm. 